\title{
Effect of Molar Ratio on Structural and Size of ZnO/C Nanocomposite Synthesized Using a Colloidal Method at Low Temperature
}

\author{
Siham Lhimr*, Saidati Bouhlassa, and Bouchaib Ammary \\ Department of Chemistry, Mohammed V University, 4 Avenue Ibn Battouta, BP 1014 RP, Rabat 10000, Morocco
}

* Corresponding author:

tel: $+212-676463299$

email: siham.lhimr@gmail.com

Received: August 8, 2018

Accepted: December 22, 2018

DOI: $10.22146 /$ ijc.37932

\begin{abstract}
In this paper we study the effects of different molar ratio $\mathrm{R}$ of $\mathrm{Zn}^{2+}$ to $\mathrm{OH}^{-}$ $(R=n O H-/ n Z n(I I)$ on the morphology, particle size and optical properties, of the precursor was investigated by varying the amount of $\mathrm{NaOH}$. Samples have been synthesized by the colloidal method at room temperature using $\left(\mathrm{ZnCl}_{2}\right)$, citric acid $\left(\mathrm{C}_{6} \mathrm{H}_{8} \mathrm{O}_{9} \cdot \mathrm{H}_{2} \mathrm{O}\right)$ and sodium hydroxide $(\mathrm{NaOH})$. The structure of $\mathrm{ZnO} / \mathrm{C}$ composite characterized by the $X$-ray diffraction patterns indicated a high crystallinity and nanocrystalline size of $\mathrm{ZnO}$ with hexagonal wurtzite structure. The morphologies of the particles have been studied with a scanning electron microscope (SEM). The existence of carbon into the composite was detected by FTIR and EDS. The optical band gap of various $\mathrm{ZnO} / \mathrm{C}$ composite was calculated from UV-Visible absorption measurement varied in the range 3.301 to $3.282 \mathrm{eV}$ according to $R$ values.
\end{abstract}

Keywords: ZnO/C composite; low-temperature synthesis; colloidal method; molar ratio $R$

\section{- INTRODUCTION}

Zinc oxide crystallizes in the typical wurtzite hexagonal structure with space group $\mathrm{P} 63 \mathrm{mc}$ and lattice parameters $\mathrm{a}=\mathrm{b}=0.325 \mathrm{~nm}$ and $\mathrm{c}=0.521 \mathrm{~nm}$ [1]. The importance of $\mathrm{ZnO}$ is due to stable chemical properties and his wide and direct band gap energy $(3.37 \mathrm{eV})$, a semiconductor material with a large exciton binding energy of $60 \mathrm{meV}$ at room temperature [2]. According to reference studies [3], doping of $\mathrm{ZnO}$ with nonmetal elements such as carbon $(\mathrm{C})$, nitrogen $(\mathrm{N})$ and sulfur $(\mathrm{S})$ leads to improve the structural, morphological and vibrational properties of $\mathrm{ZnO}$. Doping non-metal element decrease the band gap of wideband semiconductors [4]. The carbon-doped materials with a large specific surface area can be preferred for many potential applications, such as including lithium-ion batteries [5], fuel cells [6], supercapacitors [7] and photocatalyst [8]. $\mathrm{ZnO}$ nanostructures can be prepared by many methods, such as sol-gel synthesis [9], hydrothermal/solvothermal method [10], and the microemulsion method [11]. Among this synthesis route, colloidal approach compared to other methods provides a facile way for low cost and large-scale production, which does not need expensive raw materials and sophisticated equipment [12-13]. It is reported that the various applications of $\mathrm{ZnO}$ nanoparticles required the control of both physical and chemical properties such as, for example, size, size disparity, a shape, a surface state, and crystal structure [14-15]. Thus, various simple routes are developed for synthesizing $\mathrm{ZnO}$ nanoparticles with uniform shape and size. However, when the first nanoparticles are formed in a solution, they agglomerate. Nanoparticle stabilization and functionalization are then essential steps in nanomaterial synthesis. To avoid agglomeration phenomenon, nanoparticle dispersion in water is mainly employed using, furthermore, electrostatic stabilization. This process requires a rigorous control of physicalchemical parameters such as $\mathrm{pH}$, temperature, reaction time, and ionic strength of the solution. Stabilizing agents such as a molecular chain (hydrocarbon polymer) or carboxylic acids are also used to improve a high colloidal dispersion, in most cases [16-17]. The single step process without unwanted impurities is desirable for the cost-effective preparation of $\mathrm{ZnO}$ nanoparticles.

In these works, we prepared $\mathrm{ZnO} / \mathrm{C}$ nanocomposite by wet chemical synthesis via a colloidal method, at room temperature using $\left(\mathrm{ZnCl}_{2}\right)$, citric acid 
$\left(\mathrm{C}_{6} \mathrm{H}_{8} \mathrm{O}_{9} \cdot \mathrm{H}_{2} \mathrm{O}\right)$ and sodium hydroxide $(\mathrm{NaOH})$. The concentration of citric acid used as a stabilizing agent, in an aqueous medium, is an important factor in the morphology of obtaining $\mathrm{ZnO} / \mathrm{C}$ [18]. We also investigated the effect of molar ratio $\mathrm{R}=\mathrm{n}_{\mathrm{OH}} / \mathrm{n}_{\mathrm{Zn} 2+}$ with $\mathrm{R}=6.0,7.0$ and 8.0 on the structural and optical properties of the $\mathrm{ZnO} / \mathrm{C}$ composite. It is found that the structural and optical properties are improved where $\mathrm{R}$ decreases from 8 to 6 . The crystal and chemical structure of the samples was identified by powder ray diffraction (XRD) and Fourier transform infrared spectroscopy (FT-IR). The size and morphology of particles were determined by scanning electronic microscopy (SEM) and UV-Visible spectroscopy.

\section{- EXPERIMENTALSECTION}

\section{Materials}

Zinc chloride $\left(\mathrm{ZnCl}_{2}\right.$, BHD Chemicals Ltd), citric acid $\left(\mathrm{C}_{6} \mathrm{H}_{8} \mathrm{O}_{7}, \mathrm{H}_{2} \mathrm{O}\right.$, Panreac) and sodium hydroxide $(\mathrm{NaOH}$, Prolabo). Distilled water was used in the reaction system as a solvent medium and washing.

\section{Instrumentation}

The synthesized sample was characterized by X-ray diffraction (XRD) using PANalytical diffractometer with $\mathrm{CuKa}(\lambda=0.154 \mathrm{~nm})$. The infrared absorption spectra were recorded over the $4000-400 \mathrm{~cm}^{-1}$ range, on an infrared spectrophotometer with the Fourier transform, JASCO 4100. The morphology and particle size of the products obtained were analyzed by scanning electronic microscopy. The optical properties were carried out using a Perkin Elmer Lambda 900 Spectrophotometer in the UV/vis/NIR region.

\section{Procedure}

The used preparation procedure was described by Wang et al. but with the introduction of a few modifications [19]. 2.101g, $1 \mathrm{M}$ citric acid $\left(\mathrm{C}_{6} \mathrm{H}_{8} \mathrm{O}_{7}, \mathrm{H}_{2} \mathrm{O}\right)$ was dissolved in $10 \mathrm{~mL}$ of distilled water with $0.954 \mathrm{~g}, 0.7$ $\mathrm{M}$ zinc chloride $\left(\mathrm{ZnCl}_{2}\right)$ to get $0.7 \mathrm{M}$ zinc chloride and 1 $\mathrm{M}$ citric acid stirred at room temperature. Obtained media were neutralized by a solution of $1.4 \mathrm{M} \mathrm{NaOH}$ at room temperature, tree precursor solution with different ratios $\mathrm{R}=\mathrm{n}_{\mathrm{OH}-} / \mathrm{n}_{\mathrm{Zn} 2+}=6.0,7.0,8.0$ was prepared.

Synthesized colloids were oven dried at $40^{\circ} \mathrm{C}$ for 1 to 3 days, and were subsequently heated at $100{ }^{\circ} \mathrm{C}$ for 30 $\mathrm{min}$, and the resulting $\mathrm{ZnO} / \mathrm{C}$ materials prepared at room temperature the $\mathrm{ZnO} / \mathrm{C}-\mathrm{R}$ with $\mathrm{R}=6.0,7.0$, and 8.0 were denoted, thereafter, $\mathrm{ZnO} / \mathrm{C}-6, \mathrm{ZnO} / \mathrm{C}-7$ and $\mathrm{ZnO} / \mathrm{C}-8$ respectively.

\section{- RESULTSANDDISCUSSION}

\section{FT-IR Analysis}

Fig. 1 shows the FTIR spectra of $\mathrm{ZnO} / \mathrm{C}-6, \mathrm{ZnO} / \mathrm{C}$ 7 , and $\mathrm{ZnO} / \mathrm{C}-8$ sample. The absorption bands in 3380$3600 \mathrm{~cm}^{-1}$ which could be ascribed to stretching vibration and deformation of $\mathrm{O}-\mathrm{H}$ indicate the plentiful

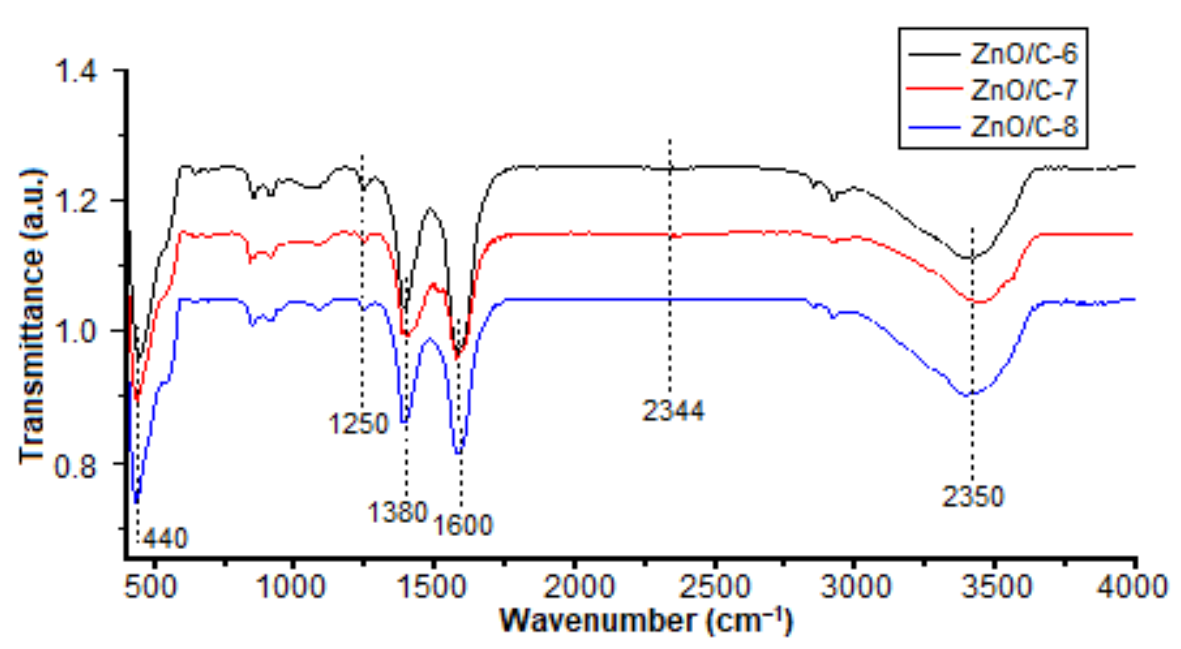

Fig 1.FT-IR spectra of the synthesized $\mathrm{ZnO} / \mathrm{C}-\mathrm{R}$ samples $(\mathrm{R}=6,7$ and 8$)$ 
existence of the hydroxyl group in $\mathrm{ZnO}-8$. The magnitudes of the peaks were lesser in $\mathrm{ZnO}-6$ and $\mathrm{ZnO}$ 7. The presences of corresponding to citrate are clearly seen at 1250,1380 , and $2344 \mathrm{~cm}^{-1}$ and are assigned to $\mathrm{CO}_{2}$. The bands at $350-600 \mathrm{~cm}^{-1}$ associated with the stretching vibration of zinc-oxygen bond confirm the formation of $\mathrm{Zn}-\mathrm{O}$ in $\mathrm{ZnO} / \mathrm{C}-6, \mathrm{ZnO} / \mathrm{C}-7$ and $\mathrm{ZnO} / \mathrm{C}-8$ [20-21].

\section{XRD Analysis}

Fig. 2 shows the $\mathrm{XRD}$ patterns of $\mathrm{ZnO} / \mathrm{C}-6, \mathrm{ZnO} / \mathrm{C}$ 7, and $\mathrm{ZnO} / \mathrm{C}-8$ samples. From Fig. 2, $\mathrm{ZnO}$ phases exhibit a wurtzite structure with the characteristic peaks at (100), (002) and (101) plans (JCPDS card No.36-1451). The peaks intensities increase with the reduction of the molar ratio until they reach the maximum value for $\mathrm{ZnO} / \mathrm{C}-6$. This implies that the latter has the smaller crystallites size.

The Scherrer formula [22] was used in the determination of particle size of crystals in the form of powder.

$\mathrm{D}=\frac{\mathrm{k} \lambda}{\mathrm{B} \cos \theta}$

where $\mathrm{D}$ is the mean size of particles $(\mathrm{nm}), \mathrm{K}(\approx 0.94)$ is a crystallite shape factor, $\lambda(0.1546 \mathrm{~nm})$ is the X-ray wavelength, $B$ is the full width at half the maximum (FWHM) in radians of the X-ray diffraction peak and $\theta$ is the Braggs' angle (deg).

The lattice parameters ( $a$ and $c$ ) have been determined by using the following formula used for hexagonal systems [23]: $\frac{1}{\mathrm{~d}^{2}}=\frac{4}{3}\left(\frac{\mathrm{h}^{2}+\mathrm{hk}+\mathrm{k}^{2}}{\mathrm{a}^{2}}\right)+\frac{\mathrm{l}^{2}}{\mathrm{c}}$

Referring Bragg law, it is possible to rewrite equation (2) as follows:

$\frac{4 \sin ^{2} \theta}{\lambda^{2}}=\frac{4}{3}\left(\frac{\mathrm{h}^{2}+\mathrm{hk}+\mathrm{k}^{2}}{\mathrm{a}^{2}}\right)+\frac{\mathrm{l}^{2}}{\mathrm{c}}$

There are two unknowns to calculate into the equation (3) Therefore, in calculating the network constant $\mathrm{a}$, the peak in the form of (hk0) should be chosen in order to eliminate the $\mathrm{c}$ of the other share, in the calculation of $c$ constant, the peak in the form (001) should be chosen to get an equation with an unknown. After choosing the appropriate peaks, the following equations are derived for the constants a and c.

$\mathrm{a}=\frac{\lambda \sqrt{\mathrm{h}^{2}}+\mathrm{hk}^{2}+\mathrm{k}^{2}}{\sqrt{3}{ }^{*} \sin \theta}$,

$c=\frac{\lambda \star 1}{\sin \theta}$

where $\mathrm{d}$ is lattice spacing, a and $\mathrm{c}$ are lattice constants, $\mathrm{h}$, $\mathrm{k}, \mathrm{l}$ are Miller indices, $\theta$ is the angle of corresponding peak and $\lambda$ is the wavelength of X-ray used (1.5402 $\AA$ ).

The volume of wurtzite unit cell for the hexagonal system of $\mathrm{ZnO}$ nanoparticles has been calculated by using the relation given below [24]:

$\mathrm{V}=0.866^{*} \mathrm{a}^{2 *} \mathrm{c}$

where $\mathrm{V}$ is the lattice volume, a and $\mathrm{c}$ are the lattice constants. The average crystallite size, lattice parameters and the lattice volume for all samples are resumed in Table 1.

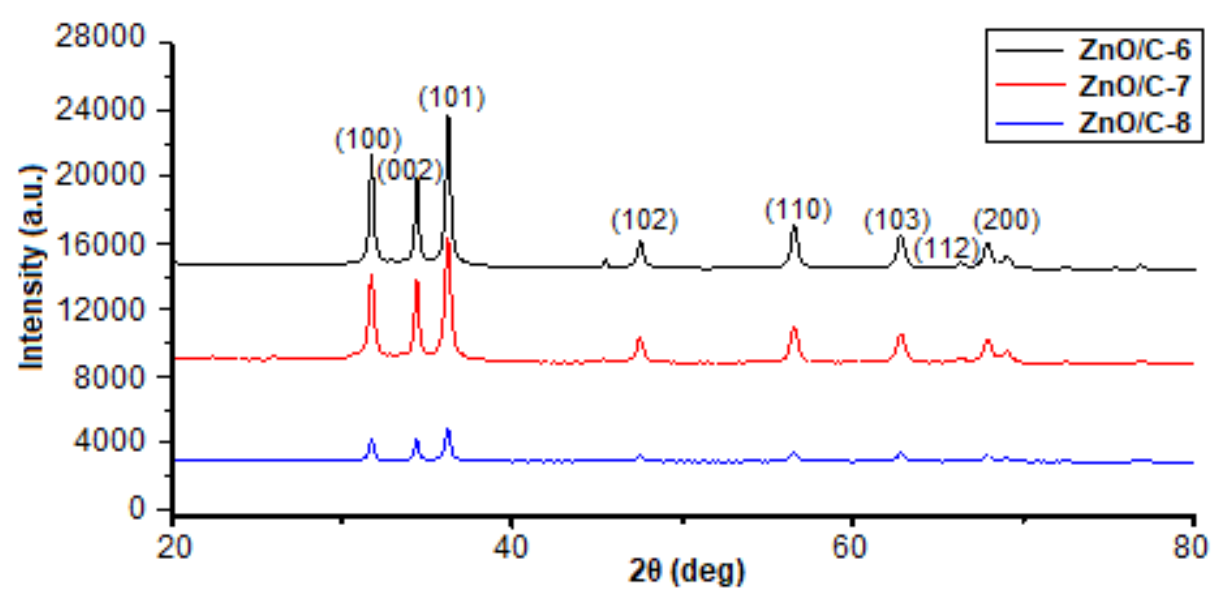

Fig 2. XRD spectra of the synthesized $\mathrm{ZnO}-\mathrm{R}$ samples $(\mathrm{R}=6,7$ and 8$)$ 
Table 1. Crystallite sizes, lattice volume and lattice parameters (a and c) for $\mathrm{ZnO} / \mathrm{C}$ nanoparticles

\begin{tabular}{lllll}
\hline $\mathrm{R}$ & $\mathrm{D}$ & $\mathrm{c}(\AA)$ & $\mathrm{c}(\AA)$ & $\mathrm{V}\left(\mathrm{nm}^{3}\right)$ \\
\hline 6 & 25.23 & 3.251 & 4.955 & 0.0454 \\
7 & 25.95 & 3.252 & 4.953 & 0.0454 \\
8 & 38.52 & 3.250 & 4.951 & 0.0453 \\
\hline
\end{tabular}

\section{SEM Analysis}

The morphology and the size of the sample particles were examined by SEM. Fig. 3 presents the SEM images and grain size distributions of the synthesized $\mathrm{ZnO} / \mathrm{C}$ samples. It could be seen that the three $\mathrm{ZnO} / \mathrm{C}$ resulting from different $\mathrm{R}$ ratios led to the formation of
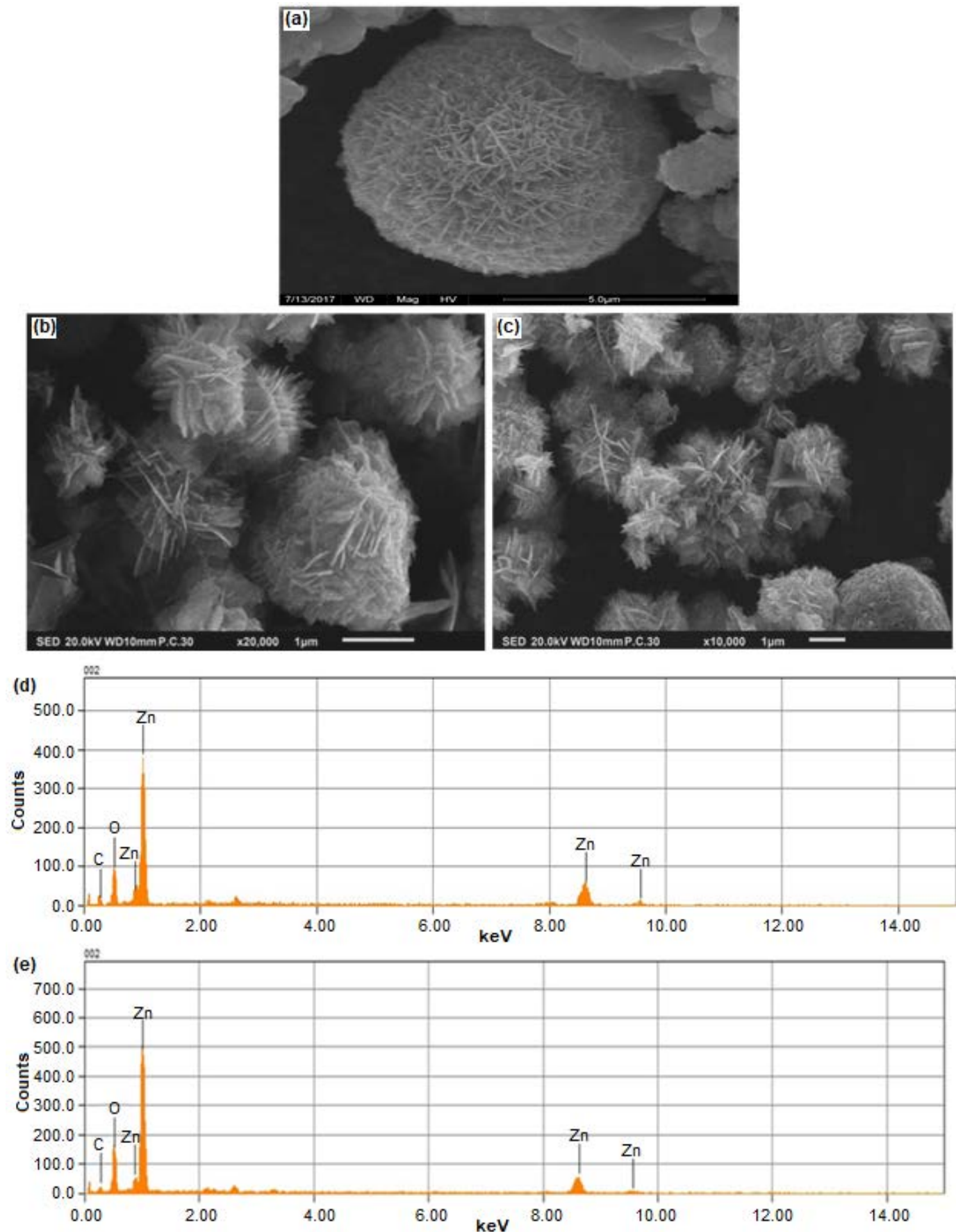

Fig 3. SEM images of the synthesized $\mathrm{ZnO} / \mathrm{C}$ samples (a) $\mathrm{ZnO} / \mathrm{C}-6$, (b) $\mathrm{ZnO} / \mathrm{C}-7$, (c) $\mathrm{ZnO} / \mathrm{C}-8$, EDS microanalyses: (d) $\mathrm{ZnO} / \mathrm{C}-7$, (e) $\mathrm{ZnO} / \mathrm{C}$ 
different morphologies. Fig. 3(a) shows the sphere is of a net grid-like morphology and a hexagonal prism. Each prism is about $1 \mu \mathrm{m}$ in diameter. Fig. 3(b) shows the morphology of the assembled $\mathrm{ZnO} / \mathrm{C}$ structures influenced by the molar ratio. The $\mathrm{ZnO} / \mathrm{C}-7$ seems to, composed of interleaving thin plates or nanosheets. These microstructures have an average particle diameter of about $1 \mu \mathrm{m}$. Fig. 3(c) The $\mathrm{ZnO} / \mathrm{C}-8$ contains flower-like structures with a diameter of $2 \mu \mathrm{m}$. The chemical composition of the $\mathrm{ZnO} / \mathrm{C}$ composite was determined by EDS, as displayed in Fig. 3(d) and 3(e), in order to show the presence of the $\mathrm{Zn}, \mathrm{O}$ and $\mathrm{C}$ elements. We can see a relatively large amount of $\mathrm{C}$ not been crystallized as previously shown in the XRD measurements. From EDX spectra the estimated amount of $\mathrm{C}$ in the sample is presented in Table 2, the content of which in the composite for the $\mathrm{ZnO} / \mathrm{C}-7$ and $\mathrm{ZnO} / \mathrm{C}-8$ is about 15 and $14 \mathrm{wt} . \%$ respectively.

Obviously, $\mathrm{C}$ atoms must distribute homogeneously in the sample, either forming an amorphous $C$ (free carbon) or incorporating with $\mathrm{ZnO}$ in the wurtzite structure (C dopants) in the former case, the amorphous $\mathrm{C}$ atoms are independent of the physical properties of $\mathrm{ZnO}$ nanocrystals. In the latter case, $\mathrm{C}$ atoms may allocate at the interstitial sites in wurtzite $\mathrm{ZnO}$ that do not form atomic bindings with host materials or they can substitute $\mathrm{Zn}$ cites or $\mathrm{O}$ cites to from $\mathrm{O}-\mathrm{C}$ and $\mathrm{Zn}-\mathrm{C}$ bonds. However, we can not estimate the realistic ration $\mathrm{C}$ dopants in the current case.

\section{UV-Visible}

The transmission spectra of the $\mathrm{ZnO} / \mathrm{C}-\mathrm{R}$ samples are shown in Fig. 4(a). The optical transmission in the

Table 2. The amount of $\mathrm{C}$ dopped $\mathrm{ZnO}$ for two molar ratios 7 and 8

\begin{tabular}{cc}
$\begin{array}{c}\text { Molar ratio } \\
\left(\mathrm{R}=\mathrm{OH}^{-} / \mathrm{Zn}(\mathrm{II})\right)\end{array}$ & $\begin{array}{c}\text { C content } \\
(\%)\end{array}$ \\
\hline 7 & 15.10 \\
8 & 14.17 \\
\hline
\end{tabular}
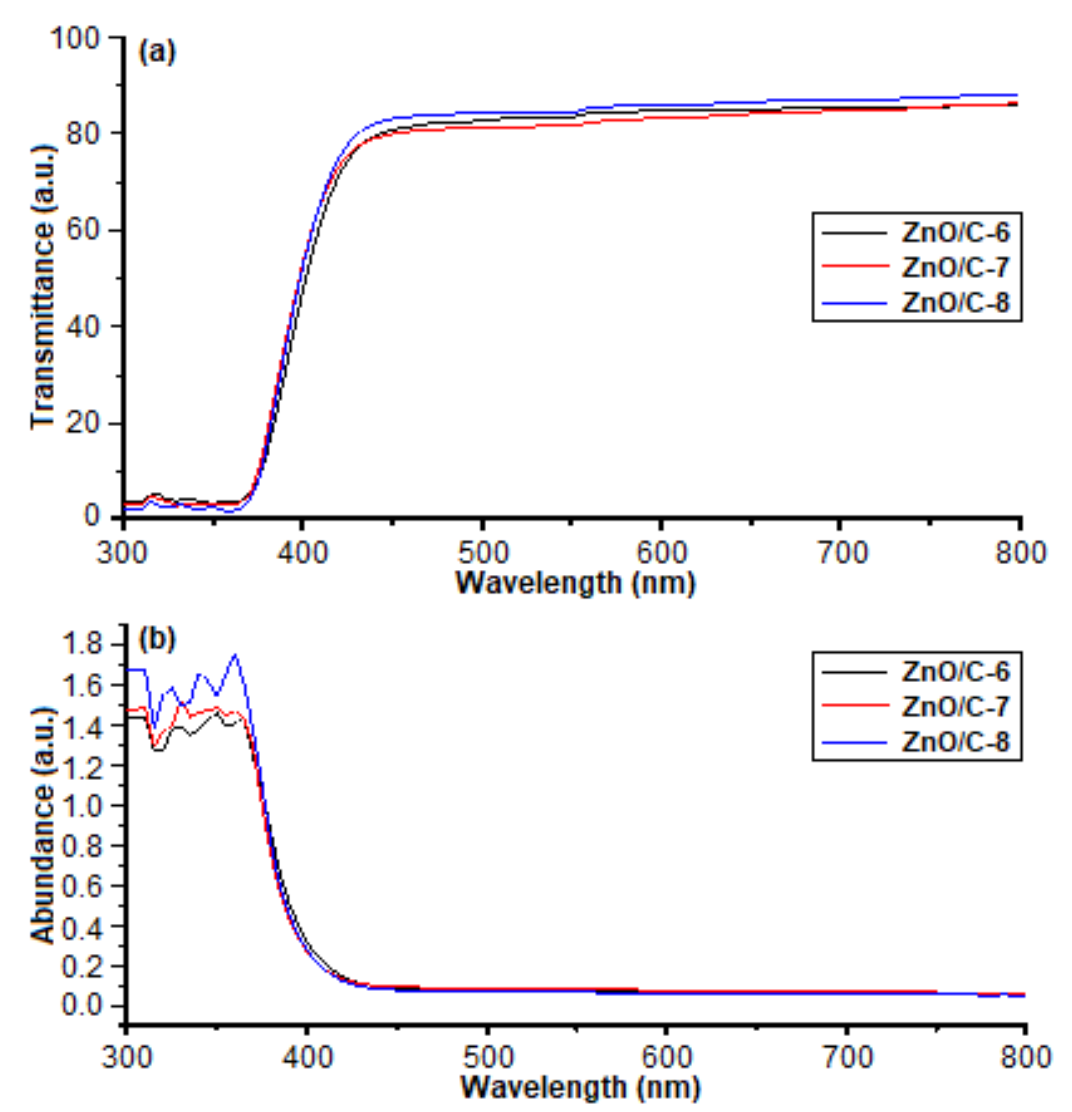

Fig 4. (a) UV-vis Transmittance spectra of the $\mathrm{ZnO}-\mathrm{R}$, (b) The Absorption coefficient of the $\mathrm{ZnO} / \mathrm{C}-\mathrm{R}$ ( $\mathrm{R}=6$, 7, and 8) 


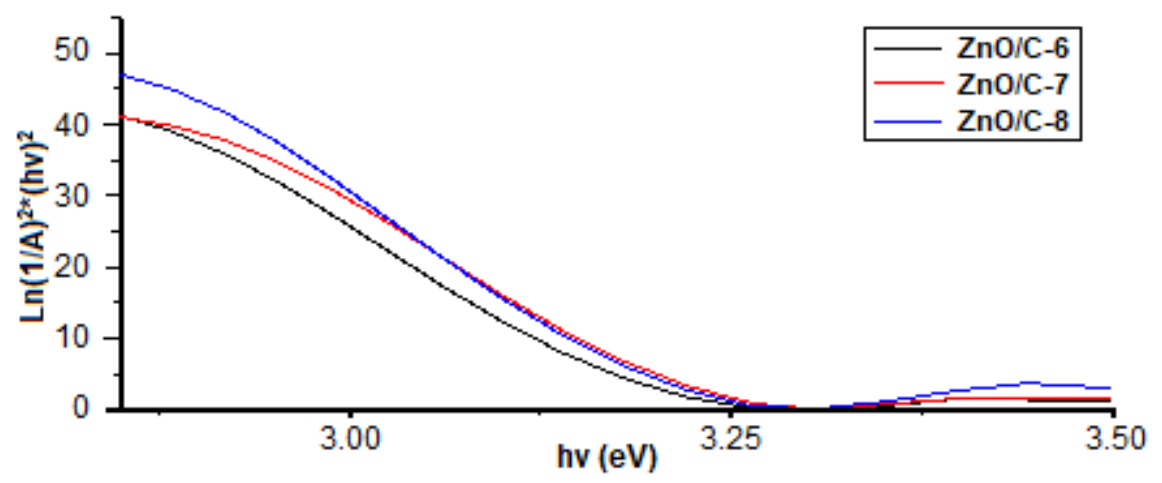

Fig 5. Optical band gap energy Eg of the $\mathrm{ZnO}-\mathrm{R}(\mathrm{R}=6$, 7, and 8)

visible region (450-800 $\mathrm{nm}$ ) for all the $\mathrm{ZnO} / \mathrm{C}-\mathrm{R}$ samples is high $(>80 \%)$, indicating that the $\mathrm{ZnO} / \mathrm{C}-\mathrm{R}$ samples with $\mathrm{R}=6,7$, and 8 are transparent in the visible region. The transmission decreases sharply near the ultraviolet region due to the band gap absorption. Fig. 4(b) illustrates the UV-Vis absorption spectrum of the samples and shows a strong exciton absorption peak at 365, 360, and $360 \mathrm{~nm}$ for $\mathrm{ZnO} / \mathrm{C}-6, \mathrm{ZnO} / \mathrm{C}-7$, and $\mathrm{ZnO} / \mathrm{C}-8$ respectively.

The variation of the absorbance according to energy using the following equation [25]:

$(\mathrm{Ln} 1 / \mathrm{A})^{2 \star}(\mathrm{h} v)^{2}=\mathrm{C}^{2 \star} \mathrm{d}^{2 \star} \mathrm{h} v-\mathrm{C}^{2 \star} \mathrm{d}^{2 \star} \mathrm{E}$

Lead to energy gap. This equation is derived from $\mathrm{A}=\mathrm{A}_{0} \exp \left(-\alpha^{\star} \mathrm{d}\right)$

where $\alpha=C\left(h^{*} v-E\right)^{1 / 2} / h^{*} v$ is the absorption coefficient, $C$ a constant, $\mathrm{E}$ the optical band gap, A the absorption and $\mathrm{d}$ the thickness of the sample.

Fig. 5 reports the plots of $(\operatorname{Ln} 1 / \mathrm{A})^{2 *}(\mathrm{Hv})^{2}$ versus photon energy for the samples. The slopes and the intercepts at the $\mathrm{h} v$ axis of the linear variation enable us to deduce the direct band gap. The direct band gap (Eg) estimates from the spectra is about 3.301, 3.294, and $3.282 \mathrm{eV}$, for $\mathrm{ZnO} / \mathrm{C}-6, \mathrm{ZnO} / \mathrm{C}-7$ and, $\mathrm{ZnO} / \mathrm{C}-8$, respectively. Slight shifts in the band gap with increased intensity was noticed due to increased molar ration R [2627].The band gap value decreases with an increase in the thickness. Earlier studies show that an increase of the surface to volume ratio with decreasing particle size leads to increasing the contribution on the surface related emission centers to the emission spectrum [28-29].

\section{- CONCLUSION}

In the present work $\mathrm{ZnO} / \mathrm{C}$ composites synthesized at different molar ratio of $\mathrm{R}$ of $\mathrm{Zn}^{2+}$ to $\mathrm{OH}^{-}$ $\left(\mathrm{R}=\mathrm{n}_{\mathrm{OH}-} / \mathrm{n}_{\mathrm{Zn}(\mathrm{III}}\right)($ with $\mathrm{R}=6.0,7.0$, and 8.0$)$ were analyzed to determine the influence of molar ratios of crystalline size, morphology and optical properties of $\mathrm{ZnO} / \mathrm{C}$ composite. X-ray diffraction showed that the prepared particles are the $\mathrm{ZnO}$ wurtzite crystalline structure. The size range of the synthesized $\mathrm{ZnO}$ particles slightly decreases with decreases the molar ratio $\mathrm{R}$ and was approximately $25-39 \mathrm{~nm}$. UV-Vis reflectances indicate the synthesized $\mathrm{ZnO}$ nanoparticles exhibit good optical properties with band gap $3 \mathrm{eV}$. The existence of carbon into $\mathrm{ZnO} / \mathrm{C}$ composite structures was evidenced by EDS and FTIR.

\section{- ACKNOWLEDGMENTS}

Authors would like to thank the National Center for Scientific and Technical Research (CNRST) of Morocco for putting at our disposal the technical facilities of the UATRS.

\section{- REFERENCES}

[1] Liu, R., Vertegel, A.A., Bohannan, E.W., Sorenson, T.A., and Switzer, J.A., 2001, Epitaxial electrodeposition of zinc oxide nanopillars on single-crystal gold, Chem. Mater., 13 (2), 508-512.

[2] Su, Y.K., Peng, S.M., Jiet, L.W., Wu, C.Z., Cheng, W.B., and Liu, C.H.,2010, Ultraviolet $\mathrm{ZnO}$ nanorod photosensors, Langmuir, 26 (1), 603-606. 
[3] Chen, L.C., Tu, Y.J., Wang, Y.S., Kan, R.S., and Huang, C.M., 2008, Characterization and photoreactivity of N-, S-, and C-doped $\mathrm{ZnO}$ under UV and visible light illumination, J. Photochem. Photobiol., A, 199 (2-3), 170-178.

[4] Lavand, A.B., and Malghe, Y.S., 2015, Visible light photocatalytic degradation of 4-chlorophenol using C/ZnO/CdS nanocomposite, J. Saudi Chem. Soc., 19 (5), 471-478.

[5] Zhang, J., Ni, S., Tang, J., Yang, X., and Zhang, L., 2016, The preparation of $\mathrm{NiO} / \mathrm{C}-\mathrm{Ni}$ composite as a binder-free anode for lithium-ion batteries, Mater. Lett., 176, 21-24.

[6] Dicks, A.L., 2006, The role of carbon in fuel cells, J. Power Sources, 156 (2), 128-141.

[7] Jänes, A., Kurig, H.S., and Lust, E., 2007, Characterization of activated nanoporous carbon for supercapacitor electrode materials, Carbon, 45 (6), 1226-1233.

[8] Chen, T., Yu, S., Fang, X., Huang, H., Li, L., Wang, X., and Wang, H., 2016, Enhanced photocatalytic activity of C@ZnO core-shell nanostructures and its photoluminescence property, Appl. Surf. Sci., 389, 303-310.

[9] Moghaddam, F.M., and Saeidian, H., 2007, Controlled microwave-assisted synthesis of $\mathrm{ZnO}$ nanopowder and its catalytic activity for $\mathrm{O}$-acylation of alcohol and phenol, Mater. Sci. Eng., B, 139 (2-3), 265-269.

[10] Hu, Y., and Chen, H.J., 2008, Preparation and characterization of nanocrystalline $\mathrm{ZnO}$ particles from hydrothermal process, J. Nanopart. Res., 10 (3), 401-407.

[11] Cai, K.F., He, X.R., and Zhang, L.C., 2008, Fabrication, properties and sintering of $\mathrm{ZnO}$ nanopowder, Mater. Lett., 62 (8-9), 1223-1225.

[12] Darezereshki, E., Alizadeh, M., Bakhtiari, F., Schaffie, M., and Ranjbar, M., 2011, A novel thermal decomposition method for the synthesis of $\mathrm{ZnO}$ nanoparticles from low concentration $\mathrm{ZnSO}_{4}$ solutions, Appl. Clay Sci., 54 (1), 107-111.

[13] Wang, H., Li, C., Zhao, H., Li, R., and Liu, J., 2013, Synthesis, characterization, and electrical conductivity of $\mathrm{ZnO}$ with different morphologies, Powder Technol., 239, 266-271.

[14] Ghorbani, H.R., Mehr, F.P., Pazoki, H., and Rahmani, B.M., 2015, Synthesis of $\mathrm{ZnO}$ nanoparticles by precipitation method, Orient. J. Chem., 31 (2), 1219-1221.

[15] Vaseem, M., Umar, A., and Hahn, Y.B., 2010, “ZnO Nanoparticles: Growth, Properties, and Applications" in Metal Oxide Nanostructures and Their Applications, Eds., Umar. A., and Hahn, Y.B., Vol. 5, American Scientific Publishers, 1-36.

[16] Sperling, R.A., and Parak, W.J., 2010, Surface modification, functionalization and bioconjugation of colloidal inorganic nanoparticles, Philos. Trans. R. Soc. London, Ser. A, 368 (1915), 1333-1383.

[17] Fiedot, M., Rac, O., Suchorska-Woźniak, P., Karbownik, I., and Teterycz, H., 2014, "Polymer Surfactant Interactions and Their Influence on Zinc Oxide Nanoparticles Morphology" in Manufacturing Nanostructures, Eds., Ahmed, W., and Ali, N., One Central Press, UK, 108-128.

[18] Cho, S., Jang, J.W., Jung, S.H., Lee, B.R., Oh, E., and Lee, K.H., 2009, Precursor effects of citric acid and citrates on $\mathrm{ZnO}$ crystal formation, Langmuir, 25 (6), 3825-3881.

[19] Wang, L., Zhao, D., Zhang, M., Wang, C., Tang, K., Zhang, $\mathrm{X}$., and $\mathrm{Xu}, \mathrm{J}$., 2014, $\mathrm{Zn}_{0.5} \mathrm{Co}_{0.5} \mathrm{O}$ solid solution nanoparticles with durable life for rechargeable lithium-ion batteries, Nano LIFE, 4 (4), 1441015.

[20] Maensiri, S., Laokul, P., and Promarak, V., 2006, Synthesis and optical properties of nanocrystalline $\mathrm{ZnO}$ powders by a simple method using zinc acetate dehydrate and poly(vinyl pyrrolidine), J. Cryst. Growth, 289 (1), 102-106.

[21] Deng, Y., Wang, G.S., Li, N., and Guo, L., 2009, Synthesis and red-shifted photoluminescence of single-crystalline $\mathrm{ZnO}$ nanowires, J. Lumin., 129 (1), 55-58.

[22] Ianoş, R., Lazău, I., Păcurariu, C., and Sfirloagă, P., 2011, Aqueous combustion synthesis and characterization of $\mathrm{ZnO}$ powders, Mater. Chem. Phys., 129 (3), 881-886. 
[23] Köseoğlu, Y., Durmaz, Y.C., and Yilgin, R., 2014, Rapid synthesis and room temperature ferromagnetism of Ni-doped $\mathrm{ZnO}$ DMS nanoflakes, Ceram. Int., 40 (7), 10685-10691.

[24] Köseoğlu, Y., 2015, PEG-assisted hydrothermal synthesis and characterization of $\mathrm{Co}_{0.1} \mathrm{Zn}_{0.9} \mathrm{O}$ DMS nanoparticles, 373, J. Magn. Magn. Mater., 373, 195199.

[25] Pankove, J.I., 1971, Optical Processes in Semiconductors, Prentice-Hall, Englewood Cliffs, New Jersey, USA.

[26] Awodugba, A.O., and Ilyas, A.M.O., 2013, Synthesis and characterization of $\mathrm{ZnO}$ nanoparticles with zinc chloride as zinc source, Asian J. Nat. Appl. Sci., 2 (2), 41-44.
[27] Bepari, R.A., and Das, B.K., 2013, Synthesis of Nanostructured $\mathrm{ZnO}$ using Zinc(II) isonicotinate tetrahydrate as precursor and studies of its photoluminescence properties, Int. J. Eng. Res. Sci. Technol., 2 (4), 120-126.

[28] Kurbanov, S.S., and Kang, T.W., 2010, Spectral behavior of the emission around $3.31 \mathrm{eV}$ (A-line) from ZnO nanocrystals, J. Lumin., 130 (5), 767-770.

[29] Kurbanov, S.S., Panin, G.N., Kim, T.W., and Kang T.W., 2009, Strong violet luminescence from $\mathrm{ZnO}$ nanocrystals grown by the low-temperature chemical solution deposition, J. Lumin.,129 (9), 1099-1104. 